\title{
PRAYER IN THE POST-EXILIC PROPHETIC BOOKS OF HAGGAI, ZECHARIAH AND MALACHI ${ }^{1}$
}

\author{
Daniel F O'Kennedy \\ Old and New Testament \\ StellenboschUniversity
}

\begin{abstract}
Certain scholars (Johnson, Miller, Reventlow, Scharbert, Rhodes, et al) declare that prayer, especially intercession, was an integral part of the prophets' ministry. It is also significant that prayer was not neglected in the post-exilic literature of the Old Testament. Many of the longer prayers originated in the post-exilic period (Ezra 9; Neh 1; Neh 9; Dan 9; 1 Chr 29:10-19; etc.). The question posed by this article is: Does prayer play a prominent role in the ministries of the post-exilic prophets Haggai, Zechariah and Malachi? One would expect a positive answer to this question. This article illustrates that there is no recorded prayer in these prophetic books and only a few indirect references to prayer (cf. Zech 7:2, 13; 8:20-23; 10:1, 6; 12:10; 13:9; 14:16-17; Mal 1:9). These passages do not refer to the prophet as petitioner, but to the interaction between YHWH and his people. Zechariah 7:13 even states that YHWH will not answer the prayers of his people. There may be different reasons for this scarcity of prayer references and the other post-exilic prophetic literature provides more questions than answers. We can probably say that prayer was not an integral part of the post-exilic prophets Haggai, Zechariah and Malachi's ministries. Prayer was overshadowed by their proclamation of the word of God and their focus on the rebuilding of the temple and post-exilic community.
\end{abstract}

Key Words: Prayer; Haggai; Zechariah; Post-exilic Prophets

\section{Introductory Remarks}

There are several scholars that believe prayer, especially intercession, was an integral part of the prophets' ministry (cf. Scharbert 1960:239; Johnson 1962:59, Reventlow 1986:245246; Rhodes 1977:107, Miller 1994:263-264). In a recent book on Old Testament prayer Thompson (2012:116) writes the following:

While it may be going too far to say that in the office of the Hebrew prophet there was the call to intercede for, as well as to proclaim to, the evidence that we have does suggest that many prophets did pray for their people. This is not to say that all prophets did intercede.

One may wonder which specific prophets did pray for their people. Prayer was not neglected in the post-exilic literature of the Old Testament. Many of the longer prayers developed during this time (e.g. Ezra 9; Neh 1; Neh 9; Dan 9; 1 Chr 29:10-19). Scholars

A shorter version of this article was delivered as a paper at the IOSOT Congress in Munich, Germany (4-9 August 2013). 
agree that the books of Haggai, Zechariah and Malachi originated during the post-exilic period and are related to the later phases of the compilation of the Book of the Twelve (Boda 2007:12-113). One would therefore expect the post-exilic prophets to be part of these 'many prophets.' The question posed by this article is: Does prayer play a prominent role in the ministries of the post-exilic prophets Haggai, Zechariah and Malachi?

The article will be structured as suggested below. After a short definition of prayer literature, all the prayer references in the abovementioned books will be examined. It is also important to understand the broader literary context of these prayer references. Therefore I shall provide a brief description of prayer in other post-exilic prophetic books, as well as prayer in the post-exilic literature outside the prophetic books. There is a scarcity of prayer references in Haggai, Zechariah and Malachi and the final section discusses possible reasons for this negligence. The summary and conclusion provide a possible answer to the research question posed by the article.

\section{References to Prayer in Haggai, Zechariah and Malachi}

Prayer can be described as communication with God. In the texts outside the prayer literature people speak about God, people or things, or with people (e.g. blessings). In the prayer literature God is addressed by human beings at their initiative (Miller 1994:33). However, we must acknowledge that it is sometimes difficult to distinguish references to prayer. In most instances the presence of particular Hebrew terms and phrases help us in this process: פלל (Hitp.-pray, intercede); חנן (Hitp. - pray, supplicate); עתר (pray, supplicate, entreat); חלה (Pi. - entreat, pray, supplicate); קרא (cry, call to the Lord); בקת (seek); שאל (ask); etcetera (O’Kennedy 1996:423; Ferris 2012:583).

The classical Hebrew stem for pray or prayer (פלל) does not occur in these books. One finds no recorded prayer ${ }^{2}$ in Haggai, Zechariah and Malachi (Rhodes 1977:110-124; Louw 1979:105). There are only a few direct or indirect references to prayer in these books.

\section{Haggai}

Haggai encourages the people of God to complete the temple so that God will be in their midst. The idea of a present God usually strengthens the idea of prayer and worship. However, this is not the case in Haggai. One finds no reference to prayer in the entire book and Thompson (2012:213) reflects on this fact:

Yet we might have expected the book of Haggai, concerned as its eponymous hero is to rebuild the temple, to have at least one reference to prayer! In comparison, how much does Nehemiah pray over his building of the Jerusalem walls!

\section{Zechariah}

In the night visions of Zechariah one finds a few questions directed to the angel or messenger of God: 1:21; 2:2; 4:11, 12, 13; 5:6, 10; 6:4 (Louw 1979:105). These passages cannot be regarded as prayer literature. In Balentine's (1993:204-205) influential book on prayer in the Hebrew Bible he mentions only one reference, namely Zechariah 11:5. This verse is one of the eighteen occurrences of the 'blessed be' sentence. In most of these cases

2 Recorded prayers are texts which record the words of the prayer in direct speech. 
the concrete experience of God's intervention evokes praise, but in chapter 11:5 it occurs in a negative or sarcastic sense. It refers to leaders who sell Hebrew people for slave labour and says 'Blessed be the Lord, for I have become rich.' This 'blessed be' sentence cannot be seen as prayer literature ${ }^{3}$ (Blank 1961:88). There are a few other passages that refer directly or indirectly to prayer and will be discussed in this section.

\section{Zechariah 7:13}

Zechariah 7:8-12 portrays that the Lord of hosts summoned his people to live just, but they refused to listen and turned a stubborn shoulder. In Zechariah 7:13 we read the following words: ${ }^{4}$

Just as, when $\mathrm{I}^{5}$ called, they would not hear, so, when they called (קרא), I would not hear, says the LORD of hosts. ${ }^{6}$

The statement in verse 13 reflects God's statements in the post-exilic text of Isaiah 66:4: '...because when I called, no one answered, when I spoke, they did not listen...' (Sweeney 2000:645). Zechariah 7:13 emphasizes that God acted toward them as they had acted toward Him. He refuses to listen to those who refuse to listen to him. Verse 14 explains that God's judgment and discipline involved more than just cutting off prayer. He 'scattered them with a whirlwind among all the nations that they had not known' (Redditt 1995:83; Boda 2004:362).

The language of Zechariah 7:4-14 displays links to the penitential prayer liturgy of the exilic period and to the vocabulary and style of the prayer in Nehemiah 9. For example the expression 'and turned a stubborn shoulder' used in Zechariah 7:11 only occurs elsewhere in Nehemiah 9:29 and the reference to 'by his spirit through the prophets' (Zech 7:12) occurs only in Nehemiah 9:30 (Baldwin 1972:147; Boda 2003:61-63).

\section{Zechariah 7:2; 8:20-23}

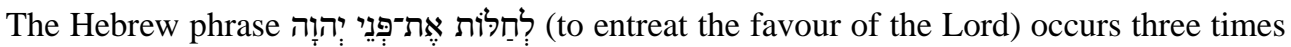
in Zechariah (Zech 7:2; 8:21, 22). According to Miller (1994:44,375) it is used as a general expression for prayer to seek God's help (cf. also 1 Sam 13:12; Ps 119:58). Apart from the expression 'entreat the favour of the Lord' one does not find the usual Hebrew words used for prayer.

Zechariah 7:2 portrays that the people of Bethel had sent Sharazer and Regem-melech and their men to 'entreat the favour of the Lord.' Zechariah 8:20-23 forms the last verses of Proto-Zechariah and says the following:

\footnotetext{
Blank (1961:88) argues that roughly two out of three times when a person blesses God in the Bible he/she intends this to express gratitude to God for a favour has done. Blank does not regard Zech 10:5 as one of these examples.

4 Citations are taken from the New Revised Standard Version of the Bible, unless mentioned otherwise.

5 The Masoretic text reads 'He called' and the NRSV follows the Syriac version reading 'I called' to harmonize this verb with 'I would not hear' (cf. suggestion of text-critical apparatus in BHS). Klein (2008:226) believes that the MT should be retained and translates it as 'He called'.

6 According to Sweeney (2000:645) the NRSV translation misrepresents the tense of the verbs. The action of the perfective verb is constative and we can perhaps accept the translation of McComiskey (2009:1134-1135): "And so it was that as I called, and they did not respond, so they would call and I would not respond, says the Lord of hosts."
} 
(20) Thus says the Lord of hosts: Peoples shall yet come, the inhabitants of many cities; (21) the inhabitants of one city shall go to another, saying, "Come, let us go to entreat the favour of the Lord, and to seek the Lord of hosts; I myself am going." (22) Many peoples and strong nations shall come to seek the Lord of hosts in Jerusalem, and to entreat the favour of the Lord. (23) Thus says the Lord of hosts: In those days ten men from nations of every language shall take hold of a Jew, grasping his garment and saying, "Let us go with you, for we have heard that God is with you."

These passages refer to the prayers of foreign people, not merely the prayers of prophets or other Israelites. It is possible that the Bethelites' recognition of the authority of YHWH and the Jerusalem community (7:2) may be seen as the beginning of a larger influx of people (O’Brein 2004:228). Zechariah 8:20-23 echoes a theme introduced in Zechariah 2:11 and reflects a strong tradition in the prophetic movement in which the nations are drawn to Jerusalem to seek YHWH (Isa 2:2-4; Mic 4:1-5) (Boda 2004:397).

The word 'many' indicates that it is not merely a few individuals, but a stream of witnesses. In Zechariah 8:20 'many' is used together with 'cities' while in Zechariah 8:22 'many' is used with 'peoples.' This emphasizes the theological belief that YHWH is ruling the entire world from his earthly locus in Jerusalem where He dwells in the temple (Meyers \& Meyers 1987:168). The plural noun עַạִ (peoples) occurs in verses 20 and 22. The question arises as to the population indicated by the use of the plural form. Many scholars assume that 'peoples' here is equivalent to 'nations' (גiוֹ) and represents foreign political entities. Meyers and Meyers (1987:436) believe that 'peoples' in these verses represent groups culturally akin to those of Yehud and 'nations' are specified in verse 23 in terms of their language uncommon to that of the Yehudites. The fact is that these passages do not refer to the prayer by prophets or the Israelites.

The divine name יִוזה צְבָאוֹת (YHWH/Lord of hosts) occurs four times in Zechariah $8: 20-23$ and is used to strengthen the authority of these prophetic words and the authority of the God to whom they pray. YHWH of hosts cannot be equated to the other surrounding gods. He is the Lord of all earthly and heavenly powers (O’Kennedy 2007:94-97).

\section{Zechariah 10:1 and 6}

In Zechariah 10:1 the prophet summons the people to ask (שאל) rain from YHWH 'who makes the storm clouds, who gives showers of rain.' In verse 6 YHWH declares in the first person:

I will strengthen the house of Judah, and I will save the house of Joseph. I will bring them back because I have compassion (רחם) on them, and they shall be as though I had not rejected them; for I am the Lord their God and I will answer (ענה) them.

The Hebrew word for answer or respond (ענה) indicates that God kept his word and answered their prayers. Why does God answer their prayers? The phrase "For I am the Lord their God" is a formula expressing a covenant relationship. God answers because He is a God that made a covenant with his people. God answers because He is a God of compassion, grace and mercy that wants to restore the relationship with his people (Klein 2008:298; Hill 2012:224). 
Verse 6 recalls God's statements concerning the restoration of the divine relationship with Israel in Hosea 2:23-25 (21-23). ${ }^{7}$ The close parallels between Zechariah 10:6 and that of Hosea 1-2 suggests that the prophet sees the fulfilment of the earlier Hosean prophecy in his own time (Sweeney 2000:673). The language of Zechariah 10:6 also echoes Isaiah 41:17 where the God of Israel promises that He will answer his people and not forsake them (Meyers \& Meyers 1993:211).

The theme of God answering the cries of the people occurs frequently in the Old Testament. For example after subduing the Philistines at Mizpah, Samuel made an offering and praised God for answering his prayer (1 Sam 7:9). Cries to God or prayer are encouraged in the foundational documents of Israel (cf. Lev 26:40-45; $1 \mathrm{Kgs} 8: 46-51$ ) and are apparent in the record of the exilic community (Ezra 9; Neh 1, 9; Lam 1-5; Dan 9) (Boda 2004:444).

\section{Zechariah 12:10}

Zechariah 12:1 till 13:9 speaks about the salvation, renewal and purification of Judah and Jerusalem. The Lord of hosts proclaims the following in 12:10:

And I will pour out on the house of David and the inhabitants of Jerusalem a spirit of

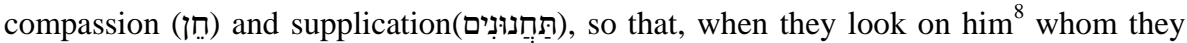
have pierced, they shall mourn for him, as one mourns for an only child, and weep bitterly over him, as one weeps over a first-born.'

This verse refers to the spirit of the leaders of Judah and the people of Jerusalem on the day of the Lord. Supplication (תַחָנוּנִים) is linked to the same root as compassion or grace (חן), but in verse 10 it denotes seeking favour from God (e.g. Ps 28:2, 6). Forms of the use of the חנן in the context of prayer are relatively late in Israel's history (cf. Dan 9:3, 17, 18, 23; 2 Chron 6:21; 31:9) (Miller (1994:44,375; Boda 2004:485).

\section{Zechariah 13:9}

Zechariah 13:9 forms part of the final section of chapter 13 (vv. 7-9) and is written in poetry. It concludes a chapter that speaks of the purification of the leaders of Judah, the inhabitants of Jerusalem and the false prophets: Verse 9 reveals the concluding conversation between YHWH and the people who has survived the refining process. The covenant relationship between God and his people will be restored:

And I will put this third into the fire, refine them as one refines silver, and test them as gold is tested. They will call (קרא) on my name, and I will answer (ענה) them. I will say, ${ }^{9}$ "They are my people"; and they will say, "The Lord is our God."

The phrase 'call on the name of God' is used more than twenty times in the Bible. It does not only refer to prayer or petition (1 Kgs 18:24-26) but also to sacrifice (Gen 12:8; 13:4; Ps 116:17) and general seeking of God (Gen 4:26; Ps 99:6; Joel 3:5 [2:32]). In some texts it seems merely to indicate recognition of God's existence (Gen 4:26; 12:8) but in Zechariah 13:9 it clearly has a connotation that YHWH is the only God who can answer prayers. He

The order of the MT will be placed first and that of the NRSV in brackets.

The MT reads 'to me.'

The words "I will say" is actually a perfect verb form in Hebrew, but most translations follow the ancient versions in treating it as an Imperfect form, which seems to fit the context better (Clark \& Hatton 2002:340). 
listens attentively to the needs of his people (cf. also Isa 30:19). This communication with God stems from a covenant relationship with Him (Meyers \& Meyers 1993:396; Klein 2008:393; McComiskey 2009:1224).

There is a close link between Hosea 2 and Zechariah 13:10. Hosea 2:16 states that the people will no longer call on the name of false gods, but the name of YHWH alone. In verse 21 YHWH promises to answer them and in verse 23 YHWH proclaims 'they are my people' and they will proclaim 'YHWH is our God' (O'Brein 2004:274).

\section{Zechariah 14:16-17}

In the strict sense of the word we cannot identify Zechariah 14:16-17 as prayer, but the reference to worship includes prayer. There is also a close relationship with the passage in Zechariah 8:20-23; therefore, we discuss it as a possible prayer reference. In Zechariah 14:16-17 we read the following:

(16) Then all who survive of the nations that have come against Jerusalem shall go up year after year to worship (חוה) the King, the Lord of hosts, and to keep the festival of booths. (17) And if any of the families of the earth do not go up to Jerusalem to worship (חוה) the King, the Lord of hosts, there will be no rain upon them.

The verb חוה translated into 'worship' refers to an action directed toward a divine figure who is recognized as being in a position of honour and authority. It may entail falling to one's knees, in front of which one places the hands to the ground (Fretheim 1997:43).

According to $14: 16$ the survivors of the nations that assembled against God will be required to go annually to Jerusalem to the festival of booths to worship God. This idea is comparable to Isaiah 56:3-8, but is not as wide ranging as the thought in Isaiah 19:19-25 which visualised Assyrians and Egyptians worshipping God in their own land (Redditt 1995:143).

Verse 17 challenges those who do not proceed to Jerusalem with a specific threat, namely absence of rain. According to Petersen (1995:157) one finds in the Mishnah an intriguing connection between the festival of booths and a lack of rain. In the Old Testament one finds a relationship between prayer and the absence of rain. In Solomon's prayer at the dedication of the temple there is a petition that God must forgive people and grant rain 'when heaven is shut up and there is no rain' $(1 \mathrm{Kgs} 8: 35-36) .1 \mathrm{Kings} 17-18^{10}$ reports that Elijah prayed for the absence of rain during the time of king Ahab but that he later prayed for rain and God answered his prayers.

Zechariah 14:16 does not merely refer to the nations that are curious and will come to see what is happening in Jerusalem. The text portrays that the nations will bow down in adoration praying to YHWH as the only King of heaven and earth. In verse 17 the emphasis does not lie on the disobedience of the nations or families of the earth, but again on the King, YHWH of hosts.

10 Cf. also the NT reference to this episode in James 5:17. 


\section{Malachi}

It is difficult to distinguish prayer references in the book of Malachi. No classical Hebrew terms or phrases for prayer are used. Lockyer (1959:11) identifies the following six 'prayer protests': $1: 2 ; 1: 6 ; 1: 7,13 ; 2: 17 ; 3 ; 7 ; 3: 8$. These 'prayer protests' indicate something of a conversation between God and his people, but cannot be regarded as prayer.

Miller (1994:44, 375) ${ }^{11}$ and Thompson (2012:213) identify at least one prayer reference, namely Malachi 1:9a: 'And now implore' (פלה) the favour of God (פְני-אֵל) that he may be gracious (חנן) to us.'

We have already mentioned that the expression "entreat the favour of God/the Lord" occurs three times in Zechariah $(7: 2 ; 8: 21,22)$. This phrase is used several times as a general expression for prayer to seek God's help (cf. Exod 32:11; 1 Kgs 13:6; 2 Kgs 13:4; 2 Chr 33:12; Jer 26:19; Dan 9:13). In most instances it is used in situations where there has been some sinful act and the petitioner is seeking to make the Lord pleasant rather than angry.

The original meaning of the Hebrew stem חלה is 'to become weak, tired, ill, feel pain' but in some instances as part of an idiomatic expression it can be translated into 'entreat, pray or beg.' Theologically, the idiom conveys the important idea that an official human entreaty can persuade God to respond to the petitioner in some way. In Malachi 1:9 the prophet summons the people to pray for grace and mercy despite their unfaithfulness (Meyers \& Meyers 1987:384; Harrison 1997:140-143; Merrill 2003:205; Hill 2012:300).

\section{Summary of Prayer References in Haggai, Zechariah and Malachi}

One can summarize the above discussion of different prayer references as follows:

- There are no recorded prayers in these books and only the following references to prayer: Zechariah 7:13; 8:20-23 (and 7:2); 10:1, 6; 12:10; 13:9; 14:16-17; Malachi 1:9. The references in Zechariah occur in both Proto- and Deutero-Zechariah.

- Different Hebrew terms and phrases are used to describe prayer: call (קרא) to the Lord of hosts (Zech 7:13) or call (קרא) to his name (Zech 13:9); entreat the favour of God (Zech 7:2; 8:21, 22; Mal 1:9); ask (שאל) the Lord (Zech 10:1); supplication

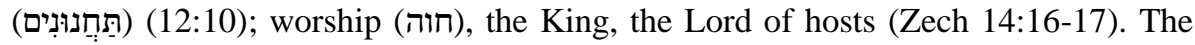
use of the different terms emphasizes that these books do not merely focus on one prayer form or genre (e.g. praise, lament, thanksgiving, intercession). The prayer references focus more on prayer in general.

- In the prayer references different names for God are being used. The prayers are directed to: the Lord/YHWH of hosts (Zech 7:2, 13; 8:20-23); the Lord/YHWH (Zech 10:1); the King, the Lord/YHWH of hosts (14:16-17) and God (Mal 1:9).

- God cannot be forced to answer the prayers of his people. He will decide in his own free will which prayers will be answered or not. We have examples of God's

Miller (1994:300) also regards Mal 2:12 as a prayer of curse for anyone who profanes the sanctionary and worship of the God of Israel: 'May the Lord cut off from the tents of Jacob anyone who does this, any to witness or answer, or to bring an offering to the Lord of hosts.' No other scholar identifies this curse as a prayer.

12 The NRSV translates it as 'implore,' but the same term is translated into 'entreat' in Zech 7:2; 8:21, 22. The word 'entreat' is perhaps a better translation. 
willingness to answer prayers (Zech 13:9), but also one example of God's unwillingness to answer prayer (Zech 7:13).

- The prayer references are not restricted to the Judeans alone. There are passages that refer to other nations praying to YHWH the God of Israel (Zech 7:2; 8:20-23; 14:16-17).

- There are no passages that refer to the prayers of the prophets. There is one indirect reference to the prayers of the leaders of Judah. Zechariah 12:10 refers to the 'spirit of supplication' of the house of David.

- Some passages convey a relationship between prayer and obedience (cf. Zech 7:13; $13: 9 ; 14: 16-17)$. God summons Judeans and foreigners to be obedient to his will. He will purify them if that is not the case or even refuse to listen to their prayers.

I can conclude that there is a scarcity of prayer references in the books of Haggai, Zechariah and Malachi. The question may be asked whether this scarcity of prayer references also applies to the other post-exilic texts.

\section{Prayer in Other Post-exilic Prophetic Books ${ }^{13}$}

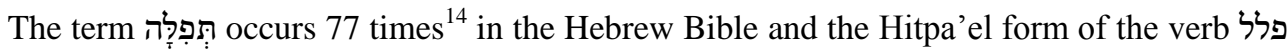
83 times. There are 9 occurrences of the noun and 20 occurrences of the verb in the prophetic books (cf. also Ferris 2012:583). The stem פלל (noun and verb) occurs only five times in post-exilic prophetic texts: Isaiah 56:7 (2x) and Jonah 2:2,8; 4:2. Most scholars will date Isaiah 56:7 during the post-exilic period, but there are some scholars that will be hesitant to date the prayers of Jonah during this period. ${ }^{15}$ I shall therefore focus on the following words of Isaiah 56:7:

...these I will bring to my holy mountain, and make them joyful in my house of prayer

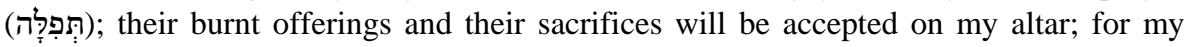

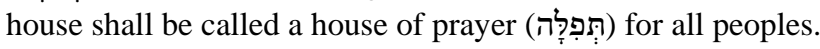

The substance of Isaiah $56: 1-8$ is a summons to those who have returned to a ruined Jerusalem to begin rebuilding their future by being good stewards of justice and righteousness. They are summoned to avoid exclusivism and specifically mentioned are the eunuchs (vv. 4-5) and the foreigners (vv. 3, 6-7). They are to be welcomed in God's 'house of prayer.' According to Miller (1994:283-284) Isaiah 56:1-8 is clearly polemical. It is directed against the Zadokite priestly hierarchy who believed that their own position at the head of the sacerdotal order is God's design for the well-being of the post-exilic community. Isaiah's oracle is a challenge to return to a more inclusive policy where the temple is a 'house of prayer for all peoples.' This view links with prayer references in Zechariah where

\footnotetext{
13 Some scholars (cf. Redditt 2008:v) regard Daniel as a prophetic book, but in this article Daniel will not be treated as one of the 'classical' prophetic books. The term 'prophetic books' refer to the 'classical prophetic books' from Isaiah till Malachi in the Hebrew Bible.

14 Statistics are drawn from the Logos Bible 4 Software programme. In some instances it differ from the statistics mentioned by the referred scholars.

15 Scholars have divergent opinions regarding the composition of Jonah, from the late pre-exilic period to the Greek period after 332 BCE (ca. 750 to 250 BCE) (Redditt 2005:258; Stuart 2012:457). Redditt (2005:258) wrote the following: 'It seems more likely that the narrative took its present form sometime in the latter half of the Persian period (after the time of Malachi)...'
} 
the other nations are praying to YHWH, the God of Israel (Zech 7:2; 8:20-23; 14:16-17). ${ }^{16}$ Isaiah 56:7 also emphasizes that sacrifice and prayer are not mutually exclusive. This passage speaks of the temple as providing the setting where sacrifice and prayer are offered (Thompson 2012:190).

There is one other significant prayer text in Isaiah 56-66 that deserves attention, namely Isaiah 63:7-64:11 (12). In this long prayer God is appealed to as Father, Redeemer and Potter. It is not implausible that parts of this prayer were being used as a communal lament by Judeans of the post-exilic community. There might have been such a group of penitent sinners during the time of Haggai and Zechariah. This prayer can be divided in the following units: the history of Israel's salvation and rebellion (63:7-14); petition for God to see and request for a theophany (63:15-64:5b); confession of $\sin (64: 4 c-7)$; final petition on behalf of the temple (64:8-12) (Werline 1998:41-45; Bautch 2003:61-63). The prayer concludes with the following petition in Isaiah 64:11 (12): After all this, will you restrain yourself, O Lord? Will you keep silent, and punish us so severely?

\section{Prayer in the Post-exilic Literature outside the Prophetic Books}

There is no scarcity of prayer literature in other post-exilic texts outside the prophetic books. The Hitpa'el verb of the Hebrew stem פלל occurs 23 times in the following postexilic texts: Job 42:8,10; Dan 9:20; Ezra 10:1; Nehemiah 1:4,6; 2:4; 4:3; 1 Chronicles 17:25; 2 Chronicles $6: 19,20,21,24,26,32,34,38 ; 7: 1,14 ; 30: 18 ; 32: 20,24 ; 33: 13$. The noun תְפִָּּה also occurs 23 times in: Job 16:17; Proverbs 15:8,29; 28:9; Daniel 9:3,17,21; Nehemiah $1: 6,11(2 x) ; 11: 17 ; 2$ Chronicles $6: 19(2 x), 20,29,35,39,40 ; 7: 12,15 ; 30: 27$; $33: 18,19$.

Apart from the statistics of the stem פלל, one finds several other recorded prayers and prayer references. The most important ${ }^{17}$ recorded prayers in post-exilic texts are the following: Daniel 9:3-19 (Prayer of Daniel); Ezra 9:6-15 (Prayer of Ezra); Nehemiah 1:

4-11 (Prayer of Nehemiah); Nehemiah 9:5-37 (Prayer of the Levites); 1 Chronicles 29:1020 (Prayer of David); 2 Chronicles 1:8-10 (Solomon's prayer for wisdom); 2 Chronicles 6:14-42 (Solomon's prayer at the dedication of the temple).

There is a close link between prayer and its socio-historical background. Prayer is in part a response to history. It arises from Israel's attempt to understand its painful experiences and desire to find its way out of misery. One must also realize that the post-exilic penitential prayers stand within a tradition. The prayers in Ezra-Nehemiah, for example, stand within a tradition that stretches back into the exile to Deuteronomy 4 and 30 and 1 Kings 8 (Werline 1998:192).

We have mentioned earlier that there is a relationship between some of the prayer references in Zechariah and the longer post-exilic penitential prayers, especially Nehemiah 9 (Boda 2003:63-64). It is clear that prayer was not neglected during the post-exilic period.

\footnotetext{
16 This is the same message of the book of Jonah where we find the other פלל refences. Jonah is sent out by God to proclaim His word to the Assyrians, a foreign nation.

17 I studied many of the recent books on Old Testament prayer and made a possible selection. There are several important prayers in Chronicles that also appear in other earlier passages of the Bible, e.g. 1 Chron 1:8-10 (Solomon's prayer for wisdom) and 2 Chron 6:14-42 (Solomon's prayer at the dedication of the temple).
} 


\section{Possible Reasons for the Negligence of Prayer in Haggai, Zechariah and Malachi}

In the previous discussion we have seen that there is a scarcity of prayer references in Haggai, Zechariah and Malachi. The question may be posed: What are the reasons for this scarcity? One could have argued that prayer did not play a major role in the post-exilic period. However, we have realized that there is a wealth of reported prayers and prayer references in other post-exilic texts. We must therefore investigate other possible reasons.

\section{Prayer not Important for the Authors or Redactors}

The first possible reason is that prayer was an important task of Haggai, Zechariah and Malachi, but the biblical authors/redactors of these books neglected referring to their prayer ministry. One can accept that the biblical authors and redactors had specific intentions when they wrote or edited the material. It may be that prayer played a more prominent role in the life of Haggai, Zechariah and Malachi, but that the redactors did not choose to report it.

Prayer does not play a prominent role in the Book of the Twelve Prophets. There are only a few recorded prayers and prayer references in these twelve books. One finds no prayer references in Obadiah, Micah, Nahum, Zephaniah and Haggai (cf. O'Kennedy 2000:338-339). We can therefore say that prayer references were neglected by the authors and redactors of these books. Unfortunately we do not know if they did it intentionally. We have no evidence of Haggai, Zechariah and Malachi's prayer ministry in other biblical or extra-biblical material.

\section{Focus on the Rebuilding of Temple and Religious Community versus Prayer}

A second possible reason is that Haggai, Zechariah and Malachi focused on the rebuilding of the temple and religious community, and that prayer did not play a prominent role in the temple. We know that Haggai and Zechariah tried to motivate the post-exilic community to rebuild the temple. Malachi prophesied after the inauguration of the temple in $515 \mathrm{BCE}$ and focused on the rebuilding of the religious community (e.g. ritual, the moral purity of the priesthood, the sufficiency of the sacrifices) (Redditt 2008:344). However, we cannot argue that prayer was neglected in the temple during the post-exilic period. In the post-exilic text of Isaiah 56:7 we learn that the temple was a place of sacrifice but also a 'house of prayer.' In Nehemiah 9 we read the long prayer of the Levites, official functionaries at the temple.

\section{Prayer was not a Major Prophetic Duty}

A third possible reason is that prayer was not a major prophetic duty of the prophets, especially Haggai, Zechariah and Malachi. Many scholars declare that prayer was one of the essential tasks of the Israelite prophets. ${ }^{18}$ Unfortunately, we cannot declare unequivocally that prayer was a major duty of all the prophets. The Old Testament portrays that prayer played a prominent role in the ministries of Abraham, Moses, Elijah, Elisha and Jeremiah, but we cannot claim the same about all the other prophets (Balentine 1984:161173; O’Kennedy 2000:329-347).

18 Cf. O’Kennedy (2000:329-330) for a more detailed discussion of these scholars. 
According to the biblical texts of Haggai, Zechariah and Malachi, prayer was not an integral part of their prophetic duty. It is perhaps unreasonable to put Zechariah and the other two prophets on the same level. There is total lack of prayer references in Haggai and only a single reference in Malachi, while Zechariah has a few references. However, we find no passage referring to these prophets' prayer ministry. If prayer was an important duty we should have had at least one reference. This does not exclude the fact that there are penitential prayer traces in the book of Zechariah (cf. Boda 2003:49-69). ${ }^{19}$

\section{Summary and Conclusion}

The question posed by this article was: Does prayer play a prominent role in the ministries of the post-exilic prophets Haggai, Zechariah and Malachi? One would expect a positive answer to this question. This article illustrates that there is no recorded prayer in these prophetic books. There is no reference to prayer in Haggai and merely one indirect reference to prayer in Malachi 1:9. We find a few references to prayer in the book of Zechariah (cf. Zech 7:2,13; 8:20-23; 10:1,6; 12:10; 13:9; 14:16-17). Different Hebrew terms are being used to describe the prayer, but no reference employing the stem פלל. These passages do not refer to the prophet as intercessor or petitioner, but to the interaction between YHWH and his people. There are even three passages that refer to other nations praying to YHWH the God of Israel (Zech 7:2; 8:20-23; 14:16-17). Only one passage states that YHWH will not answer the prayers of his people (Zech 7:13).

We have discussed three possible reasons for the scarcity of prayer references:

- Prayer was an important task of Haggai, Zechariah and Malachi, but the biblical authors/redactors of these books neglected to refer to their prayer ministry.

- Haggai, Zechariah and Malachi focused on the rebuilding of the temple and religious community, and prayer did not play a prominent role in the temple.

- Prayer was not a major prophetic duty of the prophets, especially Haggai, Zechariah and Malachi.

The exact reason remains a mystery and we can only speculate. In conclusion, we can probably say that prayer was not an integral part of the post-exilic prophets Haggai, Zechariah and Malachi's ministries. Prayer was overshadowed by their proclamation of the word of God and their focus on the rebuilding of the temple and post-exilic community.

\footnotetext{
Boda (2003:64-66) emphasizes that there is a number of links between Zechariah's prose sermons in chapters 1-8 and the penitential prayer tradition. One can perhaps say that the prose sections presupposed prayer. If one uses Werline's (2006:xv) definition of penitential prayer one cannot really declare that Zechariah was a prophet that promoted penitential prayer. The book of Zechariah refers to repentance, forgiveness, purification and fasting, but there is no reference to a specific penitential prayer.
} 


\section{BIBLIOGRAPHY}

Baldwin, JG 1972. Haggai, Zechariah, Malachi: An introduction and commentary. Nottingham: Inter-Varsity Press (TOTC).

Balentine, SE 1984. The prophet as intercessor: A reassessment. JBL 103/2, 161-173. 1993. Prayer in the Hebrew Bible: The drama of divine-human dialogue.

Minneapolis: Fortress Press (Overtures to Biblical Theology).

Bautch, RJ 2003. Developments in genre between post-exilic penitential prayers and the Psalms of communal lament. Atlanta: Society of Biblical Literature.

Blank, SH 1961. Some observations concerning biblical prayer. HUCA 32, 75-90.

Boda, MJ 2003 Zechariah: Master mason or penitential prophet, in Becking, B \& Albertz, $\mathrm{R}$ (eds.), Yahwism after the Exile: Perspecetives on Israelite religion in the Persian era, 49-69. Assen: Royal Van Gorcum.

Boda, MJ 2004. Haggai, Zechariah. Grand Rapids, Michigan: Zondervan. (The NIV application commentary.)

2007. Messengers of hope in Haggai-Malachi. JSOT 32/1, 113-131.

Clark, DJ \& Hatton, HA 2002. A handbook on Haggai, Zechariah and Malachi. New York: United Bible Societies.

Ferris, PW 2012. Prayer, in Boda, MJ \& McConville, JG (eds.), Dictionary of the Old Testament prophets, 583-587. Downers Grove: Inter-Varsity Press.

Fretheim, TE 1997. S.v. חוה NIDOTTE 2, 42-44.

Harrison, RK 1997. S.v. חלה NIDOTTE 2, 140-143.

Hill, AE 2012. Haggai, Zechariah and Malachi: An introduction and commentary. Nottingham. Inter-Varsity Press (TOTC 28).

Johnson, AR 1962. The cultic prophet in Ancient Israel. Cardiff: University of Wales Press. Lockyer, HL 1959. All the prayers of the Bible. Grand Rapids, Michigan: Zondervan.

Klein, GL 2008. Zechariah. Nashville, Tennessee: B \& H Publishing Group (The New American Commentary2aB).

McComiskey, TE 2009. Zechariah, in McComiskey, TE (ed.), The minor prophets: An exegetical and expository commentary, 1003-1244. Grand Rapids, Michigan: Baker Academic.

Louw, PU 1979. Gebed in die Ou Testament: 'n Studie van die grondbetekenis en liggaamsbelewing in die gebed. MTh Thesis, University of Stellenbosch.

Merrill, EH 2003. An exegetical commentary: Haggai, Zechariah, Malachi. LLC: Biblical Studies Press.

Meyers, C \& Meyers, EM 1987. Haggai, Zechariah 1-8. New York: Doubleday (AB 25B). Meyers, C \& Meyers, EM 1993. Zechariah 9-14. New York: Doubleday (AB 25C).

Miller, PD 1994. They cried to the Lord: the form and theology of Biblical prayer.

Minneapolis: Fortress Press.

O’Brein, JM 2004. Nahum, Habakkuk, Zephaniah, Haggai, Zechariah, Malachi. Nashville: Abingdon Press (Abingdon Old Testament Commentaries).

O'Kennedy, DF 1996. Prayer: An integral part of the Old Testament. Scriptura 59, 421-433. 
http://scriptura.journals.ac.za

Prayer in the Post-Exilic Prophetic Books of Haggai, Zechariah and Malachi

- 2000. Were the prophets really intercessors? OTE 13/3, 329-347.

- 2007. The use of the epithet יהוה צבות in Haggai, Zechariah and Malachi. JNSL 33/1, 77-99.

Petersen, DL 1995. Zechariah 9-14 and Malachi. Louisville, Kentucky: Westminster John Knox Press (OTL).

Redditt, PL 1995. Haggai, Zechariah, Malachi. Grand Rapids: Eerdmans (NCB). 2008. Introduction to the prophets. Grand Rapids: Eerdmans.

Reventlow, HG 1986. Gebet im Alten Testament. Stuttgart: W Kohlhammer.

Rhodes, AB 1977. Israel's prophets as intercessors, in Merrill, AL \& Overholt, TW (eds.), Scripture in history and Theology: Essays in Honor of J Coert Rylaarsdam.

Pittsburgh: Pickwick Press.

Scharbert, J 1960. Die Fürbitte in der Theologie des Alten Testaments. Theologie und Glaube 50, 321-338.

Stuart, D 2012. Jonah, Book of, in Boda, MJ \& McConville, JG (eds.), Dictionary of the Old Testament Prophets, 455-466. Downers Grove: InterVarsity Press.

Sweeney, MA 2000. The twelve prophets Vol 2. Collegeville, Minnesota: Liturgical Press (Berit Olam).

Thompson, MEW 2012. I have heard your prayer: The Old Testament and prayer. Eugene, Oregon: WIPF \& Stock.

Werline, RA 1998. Penitential prayers in the Second Temple Judaism: The development of a religious institution. Atlanta, Georgia: Scholars Press. 